\title{
General Transcription Factor 3C Polypeptide 4
}

National Cancer Institute

\section{Source}

National Cancer Institute. General Transcription Factor 3C Polypeptide 4. NCI Thesaurus. Code C29684.

General transcription factor 3C polypeptide 4 ( $822 \mathrm{aa}, \sim 92 \mathrm{kDa}$ ) is encoded by the human GTF3C4 gene. This protein plays a role in RNA polymerase III-mediated transcription and histone acetylation. 